\title{
Rethinking remediation: Mine reclamation, environmental justice, and relations of care
}

\author{
Caitlynn Beckett (Memorial University) \\ Dr. Arn Keeling (Memorial University)
}

\begin{abstract}
:
To date, research on mine remediation in North America has focused primarily on technical management; relatively less is known about the historical, political and social dimensions of remediation. Remediation, as a continuation of the mining process, alters local landscapes and economies and can be both dangerous and beneficial for surrounding communities. Because remediation projects tend to focus on the technical aspects of clean-up, such projects risk overlooking the environmental injustices associated with past development and obscuring blame or responsibility from industry and government for environmental degradation. Insofar as it is understood as cleaning up or repairing environmental damage, remediation is generally seen as 'doing the good' and is less amenable to political or ethical challenges based on community concerns or values. This paper argues that greater attention needs to be paid to public participation and justice concerns associated with cleaning up mine sites. Drawing from the literatures on ecological restoration, environmental justice, reconciliation, discard studies, and perpetual care, we highlight critical, yet overlooked issues in the remediation of post-mining landscapes. We argue that remediation projects present a unique opportunity for the negotiation and articulation of morals, values, histories, and physical experiences associated with mine sites and we seek to re-frame remediation as an ongoing, creative process of community healing.
\end{abstract}

Key Words: Mine remediation, restoration, environmental justice, reconciliation, matters of care Word Count: 6070

Industrial scale mineral extraction engenders some of humanity's most dramatic and enduring landscape transformations. Open-pit or strip mining methods completely remove topsoil as "overburden," often leaving behind landscapes hostile to recolonizing vegetation. Similarly, the disposal at the surface of non-ore-bearing material ("waste rock") or of the by-products of mineral extraction (tailings) provides dramatic, visible, and long-lasting evidence of mining's environmental transformations. These are not simply rock piles; they may present chemical and physical environmental hazards, from the erosion or failure of tailings impoundments, to the slow leaching of heavy metals into local waterways, to acute environmental toxicity from acid rock 
drainage (Hudson-Edwards et al., 2011). Mining's modification of the surface and subsurface environments may persist for centuries, or even indefinitely, after the supposed 'end' of mining.

In recent decades, efforts to clean-up, restore or remediate mine impacts have gained momentum under the influence of growing environmental concern and regulation, and corporate embrace of more 'sustainable' mining practices (Hilson, 2000, Hilson and Murck, 2000, Whitmore, 2005). Technical strategies for mine remediation such as acid rock drainage management, the construction of tailings covers, revegetation, soil decontamination, and water treatment are the focus of extensive research efforts, including frequent expert conferences (Lottermoser, 2010; Pepper et al., 2014; Hockley and Hockley, 2015). At the same time, many government regulators have begun developing mine closure guidelines (Worrall et al., 2009; Dance, 2015; Bainton and Holcombe, 2018).

While there has been increasing attention to the technical, environmental, and engineering challenges of remediation, there has been less attention given to public participation and community values associated with cleaning up mine sites (Banfield and Jardine, 2013). This gap arises from a variety of factors. First, in spite of a growing literature on the socio-economic dimensions of closure as part of the 'mining cycle' (Laurence, 2006; Halvaksz, 2008; Pini et al., 2010; Browne et al., 2011; McDonald et al., 2012; Keeling and Sandlos, 2015; Rixen and Blangy, 2016; Kivinen, 2017; Bainton and Holcombe 2018), remediation is often overlooked in public and scholarly debates over cumulative environmental impacts, social license, and community engagement (Smith, 2014; Langhorst and Bolton, 2017). Second, mine remediation is dominated by engineering and environmental expertise around geochemistry, hydrology, and risk management, and debated in highly technical forums like environmental assessment hearings. Even when technical descriptions of remediation are presented to the public, these options are outlined only after experts have already defined the problem and the possible solutions (Ottinger, 
2013; Bergmans et. al, 2015). In this sense, remediation is "rendered technical" (Li, 2007) and tends to limit or circumscribe public participation or non-expert assertions surrounding risk and remediation goals (Krupar, 2013; Tsosie 2015; Sandlos and Keeling 2016). Finally, insofar as it is understood as cleaning up or repairing environmental damage from mining, remediation is seen as improving the environment and "doing the good," and is therefore less amenable to political or ethical critique.

Yet the generally positive association of remediation with "cleaning up" post-mining sites ignores the fact that simply containing and managing a toxic site is usually insufficient to deal with the broader histories, impacts, and liabilities connected to contaminated sites, and the challenges of perpetual care for these landscapes (Kempton et. al., 2010; Storm, 2014; Langhorst and Bolton, 2017). Around the world, large-scale mining has often left a legacy of environmental damage and social displacement for Indigenous communities and lands (Roche and Judd, 2016; Horowitz et al., 2018). Referring to such sites as “zombie mines," Keeling and Sandlos (2017) argue mine remediation and redevelopment may reawaken historical wounds associated with negative social, economic, or environmental legacies of past developments. Because mine remediation projects tend to focus on the technical, scientific or risk management aspects of clean-up, such projects risk perpetuating or re-inscribing these environmental injustices and obscuring industry and government blame or responsibility for environmental degradation (Dillon, 2014).

To address these concerns, this paper argues for an expanded definition of mine remediation that encompasses concepts of social justice, repair, mediation, reconciliation, and care. Drawing from literatures on ecological restoration, discard studies, environmental justice, repair, and 'matters of care,' this review highlights critical, yet overlooked issues in the remediation of post-mining landscapes, particularly as it affects local communities. Recent 
ecological restoration theory emphasizes the importance of morals, ethics and values in the recreation of damaged landscapes. Discard studies and environmental justice research provide a conceptual framework for identifying spatial and temporal injustices associated with mineral extraction, and its implication in processes of displacement and dispossession. Engaging theories of repair and 'matters of care' push remediation beyond the act of cleaning up toxic and degraded landscapes, towards a focus on the ongoing processes of trust building, reconciliation, and perpetual care for humans, animals and environments alike. By embracing these concepts, we argue, remediation projects present an opportunity for the negotiation and articulation of the layered histories, presents and futures associated with contaminated mine sites. By engaging local and Indigenous communities on these questions, remediation projects may also facilitate discussion about relationships to land, perpetual care and future land uses.

\section{Remediation and Restoration: Definitions and Contexts}

Although terminology varies between different jurisdictions and contexts, increasing attention has been devoted to mine closure and remediation in response to rising concerns in the late twentieth century over mining's environmental impacts (Smith, 1987; Hockley and Hockley, 2015). In North America (where the authors are based), post-closure environmental clean-up activities are typically referred to as remediation, although other terms such as rehabilitation and reclamation are often used interchangeably, with some temporal and regional variation. ${ }^{1}$

According to Lima et al. (2016, p. 227) reclamation "aims to recover key ecosystem services and biogeochemical functions," while rehabilitation "implies a repurposing of the landscape".

\footnotetext{
${ }^{1}$ For example, in Northern Canada, the terms remediation and reclamation are used most often; however these terms have changed throughout time, and other terms such as rehabilitation are more popular elsewhere in North America. American management plans often use reclamation, rehabilitation or restoration. See: Hockley and Hockley, 2015; Dance, 2015; Steenhof, 2015.
} 
Reclamation or rehabilitation thus imply the return (or creation) of some kind of value or utility to the landscape, alongside concerns of remediating or mitigating contamination. Joly (2017, p. 166) argues that traditional remediation and reclamation approaches often "prioritize a single or narrow set of values, reducing both the spatial-material-temporal complexities and 'thickness' of post-mining landscapes and the diversity of past and contemporary values projected onto them." In the majority of cases, remediation projects focus on removing contaminants or stabilizing them on site, and reclaiming (where possible) some elements of pre-mining ecologies, with little recognition of the 'thickness' of these landscapes as spaces of social interaction with contested histories and meanings.

To restore means to bring about a former state or to return to health, and the term restoration is often used in regard to the restoration of art, historical buildings, and ruins (Hall, 2005; Howe et al., 2016; Rohwer and Marris, 2016). Ecological restorationists work to bring back idealized versions of nature, and therefore are "automatically testing assumptions about past landscapes and the human role in the past" (Hall, 2005, p. 3). When used in the context of mining, restoration typically refers to an attempt to "reinstate the original functions of the soil in full measure," with the goal of restoring ecological health or integrity (Bradshaw, 1997, 256; Cooke and Johnson, 2002; Peachmann, 2009; Kivinen, 2017). Initially, in the late $20^{\text {th }}$ century, government clean-up programs in North America focused on efforts to restore land to an optimum state by using supposed 'past conditions' as a reference point (Brooks, 2015; Langhorst and Bolton, 2017). Such approaches were largely based on Western scientific approaches to land use planning and focused on identifying and containing point sources of pollution while 'replacing' the former landscape (Hobbs, 2013). In reality, the majority of mine reclamation sites fall short of true restoration: the extensive transformations wrought by extractive activities (including overburden removal, excavation of shafts and pits, waste dumping, and contamination) 
mean it is nearly impossible to actually restore a site to full ecological integrity. Nevertheless, recent debates in the literature on ecological restoration provide important insights into the politics and social dimensions of landscape repair.

In the 1990s, debates over ecological restoration emerged critical of the idea that landscapes could actually be returned to some former "pristine" state or function (Hobbs and Norton, 1996). Increasingly, scholars characterized restoration as a value-laden and anthropocentric practice, preoccupied with the 'improvement' of ecosystems simply for the use or aesthetic value of humans (Katz, 1997; Elliot, 1997). However, these authors weren't necessarily arguing against cleaning up contamination. Katz instead recognizes that restoration is fundamentally a process of human valuation:

We are not restoring nature: we are not making it whole and healthy again. Nature restoration is a compromise... We are putting a piece of furniture over the stain in the carpet, for it provides a better appearance... it would be much more significant to prevent the causes of the stains (Katz, 1997, p. 102).

Other observers, acknowledging this critique, suggested that, even if 'restored nature' is understood as a culturally produced artefact, the restoration of (positive) human relationships with nature remains possible (Smith, 2014). For instance, Rohwer and Marris propose a redefinition of restoration to indicate a "restoration of moral value rather than a restoration of a historical state" (2016, p. 677). They emphasize that when talking about restoration, we need to get "comfortable talking about choices, intentions, values and justifications in a world where historical fidelity no longer reigns supreme" (Rohwer and Marris, 2016, p. 678). While memorializing the past, Smith suggests, restoration has the potential to foster a new 'sense of place,' and can restore "faith and confidence in an area" (Smith, 2014, p. 300). Whether conceived in terms of 'moral restoration' (Hobbs, 2013) or 'ecological redemption' (Smith 2014), restoration is increasingly understood in terms of how communities can create or recover 
economic, cultural and social value through the processes of healing environmental (and, perhaps, its associated social and cultural) damage (Hourdequin and Havlick, 2015).

Mine remediation practices reveal similarly contested cultural values and assumptions about degradation and nature. For example, Robertson outlines several cases of mines in the United States where locals have fought to preserve some of the industrial features that defined the mining landscape, such as tailings piles, while still protecting community and environmental health (Robertson, 2006). In this sense, the landscape degradation and change caused by mining became a part of local identities (Francaviglia 1991; Goin and Raymond, 2004). However, it is also important to question whose cultural values and land uses are prioritized, as mining developments and remediation have repeatedly overlooked and undermined treaty agreements and Indigenous sovereignty across North America (LaDuke, 2005; McGregor, 2018). Different community members can have different understandings of the same place caused by a variety of experiences, such as discrimination, racism, sexism, and economic and political marginalization (Volyes, 2015; Leech, 2018). Beyond different 'senses' of one place, some groups may have entirely different ontological frameworks that structure environmental relationships (Bawaka Country et. al., 2016).

These debates around restoration and landscape values illustrate that part of rethinking remediation entails addressing the need to repair social relationships as well as environmental conditions, as relationships developed through mining have often been exploitative for local people, especially Indigenous communities. In a broader, less technical sense, remediation is related to remedy: a "medicine or treatment that relieves pain," or "a way of solving or correcting a problem" (Merriam-Webster Dictionary, 2016). The root word 'mediate' also points to interesting ways to rethink remediation. Mediating can be seen as the (re)forming of relationships. Re-mediation therefore, could potentially be seen as the re-ordering or repairing of 
relationships (France, 2008). Additionally, framed as a form of mediation, remediation can be used as a process to address harmful relationships between humans, non-humans and land.

Academic and technical discussions regarding mine remediation and reclamation rarely acknowledge these recent debates surrounding ecological restoration and cultural values. In remediation projects, the politics of who defines the past, and how this past is negotiated, articulated and memorialized is typically overlooked (Baeten, 2017). Remediation projects rely on narratives of toxicity and containment, often forgoing discussions on heritage, remembering, and healing. By contrast, ecological restoration literature has increasingly critiqued the ideals of recreating some past 'wilderness,' and has illuminated power struggles implicit in what is 'covered up' and what is remembered. Identifying the goals of mine remediation, we argue, should similarly entail an articulation and justification of values: questions of morality, redemption, the restoration of cultural, social, and economic value, and recognition of conflicting experiences and ontologies of place, are all essential parts of the healing process. In the following sections, we draw out these implications by mobilizing insights from the literatures on critical discard studies, environmental justice, repair and 'matters of care,' and outline how they contribute to a framework for rethinking remediation.

\section{Landscapes of Waste and Toxicity}

Post-mining landscapes are fundamentally defined by wastes: soils and vegetation removed as 'overburden,' waste rock piles accumulated from mining, tailings from mineral processing, 'wasted' landscapes of open pits, derelict mine works, and even abandoned communities and infrastructures. Social scientific scholarship on waste and 'critical discard studies' (Liboiron, 2014) highlights the importance of what Dillon (2014) calls “waste formations," revealing how wastes are systematically produced, managed and re-valued. How we 
define and manage waste, pollution, and environmental degradation reflects the social relations and structures within which such harms are produced and distributed (Gabrys, 2009; Liboiron et $a l ., 2018)$. Discard studies also prompts analysis of how the waste was created and managed in the past, how this material will act in the future, and the cultural, environmental, and economic valuations of this waste (Reno, 2015). Often in the case of mine remediation, contaminants are either contained and a community must live with the waste far into the future, or the contaminants are moved elsewhere and become someone else's problem, exacerbating issues of discrimination and environmental injustice (Lerner, 2010). Inherent in such questions are the challenges of managing the material characteristics, temporalities, and geographies of waste.

Remediation objectives are intimately tied to the perceptions and values of 'wasted' land: is mined land considered a toxic wasteland, an unused barren landscape, a historically treasured site, a 'home' for survival and (re)production, or a degraded sacred space (Kuletz 1998; Krupar 2011; Voyles, 2015)? As mentioned, mine wastes can be considered industrial ruins, associated with contested versions of history (Robertson 2006; Mah, 2012; Cater and Keeling 2013). Sebastien Ureta suggests that mining ruins also encompass contaminants themselves and can be seen as "chemical rubble... for which we have to take responsibility just as much as we have for more conventional ruins" (2012, p.3). Identifying differing perceptions and experiences of waste amongst different actors and outlining shared objectives can help to define how a community values the mine site, which in turn helps to define and direct the parameters of remediation alongside scientific assessments (Quivik 2001; Leech, 2011).

Waste is often perceived as the opposite of economic value; indeed, "waste is a category formed always in relation to value" (Dillon, 2014, p. 1207). Some mine wastes may become "recommodified' and transformed from waste into an economically valuable commodity (HudsonEdwards et al., 2011). Other wastes, such as overburden and waste rock, are not considered 
'toxic' and are used in building dams, roads and other infrastructure (Lottermoser, 2010). Mining infrastructure such as mine headframes can be considered waste to be removed, or preserved and revalorized as historical monuments (Baeten 2017). Most recently, as high-grade ore bodies become increasingly rare and with changes in technology, what was once considered waste may again be mined. In these ways, "mining by-products and landscapes may shift between the categories of 'waste' and 'value'” (Keeling, 2012, p. 553), depending on economic, environmental and cultural considerations.

Addressing mining's waste landscapes brings into focus the spatial challenges entailed in pollution and remediation. Mine wastes leak and permeate barriers, transforming into different entities in the process (for instance, acid rock drainage from tailings piles [Baeten et. al., 2016]). In addition, remediation might not entirely clean up a site and often does not extend beyond certain arbitrary boundaries such as mining leases or territorial boundaries, disregarding the ability of waste to flow and change (Gregson and Crang, 2010; Reno, 2015). Similar to early ecological restoration practices, remediation often focuses on fixing or containing point sources of pollution, but may not account for long-term effects 'downstream,' or outside the physical limits of the mine site. For example, sediments in rivers are a source of long-term contamination that is difficult to track, map, quantify and remediate (Bird, 2016). Such examples emphasize the spatial challenges of waste containment and stabilization, which requires continual monitoring, and re-evaluation as waste moves and changes.

The extended temporalities of mine waste can also further complicate remediation projects. The legacies of mines, in the form of degraded ecologies or persistent toxicity, can continue to haunt the surrounding environment and nearby communities for generations (Keeling and Sandlos, 2017). Over time, mining landscapes may shift from landscapes of ruination to landscapes of regeneration and reuse, to demolition and ruination once again. As Nixon argues, 
pollution can be understood as a form of "slow violence," as its cumulative effects influence communities for generations to come (2011). Rather than a sudden, disruptive event, toxic waste manifests as a "slow disaster," resulting in "chronic dread" and a sense of helplessness among those exposed (Erikson 1994). Gray-Cosgrove et al., argue that remediation itself is implicated in the slow disaster of mine contamination, "when efforts to remediate and depollute in the face of extremely long-lived pollutants are a type of disaster in and of themselves" (2015, p. 3). Without a community discussion on these questions, the potential for waste to become a slow disaster increases. In such cases, remediation becomes a reactionary (and incomplete) response to slow disasters rather than a long-term solution.

Despite the complex temporalities of degradation, contamination, and recovery within these wasted landscapes, mine remediation increasingly focuses on creating a site that requires minimal long-term monitoring and management of waste, the ideal being a 'walk-away' solution. However, this is rarely the case, and more discussion about perpetual care plans for permanently degraded sites is necessary (O’Reilly, 2015). Research on long-term radioactive waste management has begun to hypothesize possible ways to use physical barriers and passive institutional controls such as text and symbols to ensure that people in the future know how to avoid disturbing that site (Benford 1999). Increasingly, researchers, companies and governments working with nuclear waste are looking at the importance of involving citizens in planning processes (Ialenti 2014; Bergmans et. al., 2015; Cram, 2015). However, beyond discussions on the containment of nuclear waste, mine remediation practices more broadly have largely failed to deal adequately with the prospects of perpetual care of mine sites on large temporal and geographic scales. While there are important differences between remediating mine sites and managing nuclear waste repositories, there are lessons to be learned from research on nuclear waste management, as many mine wastes (including sites like Montana's Berkeley Pit or 
Canada's Giant Mine) pose similarly long-term management challenges (Kuyek, 2011; Leech, 2018).

\section{Justice and Remediation}

A discard studies perspective emphasizes that mine waste and ruins must be understood as a fundamental part of the system that produces them. Thus, alongside the material, geographic and temporal characteristics of mine waste, understanding the colonial, racial, and gendered relations within which waste is generated, contained, and managed carries important implications for best practices of remediation. The potential for continuous pollution or contamination produces uneven geographies of exposure and toxicity (Gray-Cosgrave et al. 2015; Liboiron et al., 2018). Placing remediation within an environmental justice (EJ) framework helps to address the multi-layered human and non-human relationships connected to degraded industrial environments. An EJ approach situates environmental degradation within local political contexts and power structures, identifies instances of inequality and disenfranchisement, and provides a basis for calls to action. Within the EJ literature, there has been a shift away from questions of the distribution of environmental hazards, towards a broader conceptualization of EJ that stresses the need to address the contexts and processes within which environmental inequalities are actually produced (Mohai et al., 2009; Holifield, 2012). However, while identifying instances of inequality and power imbalances related to environmental degradation, EJ literature often overlooks the creation, geography and temporality of mine waste itself. Therefore, combining an EJ approach with discard studies, as outlined above, aids in identifying and addressing both the political and material contexts of mine waste and the remediation of such waste.

Mobilizing concepts from environmental justice, global scholarship on mining and Indigenous peoples emphasizes the role of mining in processes of colonial dispossession and 
marginalization (Gedicks, 2001; Martinez-Alier, 2001; Ali, 2003; Ballard and Banks, 2003; Keeling and Sandlos, 2009; Bebbington et al., 2008; Horowitz et al., 2018). For example, in her recent analysis of the effects of historic uranium mining on Diné (Navajo) health and way of life, Voyles argues that through the settler colonial process of 'wastelanding,' abandoned mines and industrial sites - as well as the land itself — are produced and perceived as wasted, derelict or useless. The people who live in and rely on these landscapes are also 'wasted' in the sense that their bodies and their cultures become a waste product of extractive industries, enabling accumulation through dispossession and degradation (Hall 2012; Voyles, 2015; Women's Earth Alliance, 2016; Simpson, 2017).

Acknowledgement of these historic and ongoing colonial relations is typically absent from environmental remediation policy and planning. Indeed, remediation's focus on technical fixes potentially allows responsible parties to cleanse themselves of social responsibility and overlook past injustices. Dillon argues that narrow, technical approaches to remediation, reclamation and restoration allow governments and industry to "defer responsibility for the social effects of industry," instead presenting remediation as an environmental benefit or improvement (2014, p. 1218). Yet technocratic approaches to re-greening and clean-up also mobilize and reinforce certain kinds of power through expert knowledge, monitoring, and control of the site (Krupar, 2013; Ottinger, 2013). Such technical and legalistic efforts to define and remediate landscapes of exposure may remain entangled within colonial jurisdictional "mitigation politics" (Hoover 2017) that limit liability and circumscribe community concerns and experiences of environmental displacement (Leddy 2013; Wiebe 2017; Joly, 2017). In this sense, remediation may perpetuate, rather than repair the social and environmental injustices associated with the original development. 
Recognizing the colonial context of both mine degradation and remediation, Indigenous (Yaqui) legal scholar Rebecca Tsosie develops a comprehensive "ethics of remediation" rooted in both Indigenous and Western legal orders. In her analysis of Indigenous claims for restitution relating to the history and legacies of uranium mining in Diné (Navajo) Country, Tsosie argues that, beyond the mitigation of contamination and restoration (as far as possible) of pre-mining ecological conditions, remediation should encompass the objectives "to repair social or political connections, restore trust, and instill a sense of peace" (2015, p. 250). For Tsosie, the current practice of remediation by U.S. government authorities remains rooted in the persistent inequality and injustices that resulted in the dispossession of Diné people and the degradation of their territories through mining in the first place. These effects are perpetuated in the present through the "epistemic injustice" of science-based policy approaches that "omit the testimony of Indigenous community members as 'experts' in favour of scientific and economic accounts of harm" (Tsosie, 2015, p.271).

Tsosie proposes an ethics of remediation that requires holistic attention to inequities in environmental, health, and socioeconomic conditions (past and present); acknowledges Indigenous sovereignty and self-determination as intrinsic to repairing relationships between people and land; incorporates Indigenous land values and knowledges; and attends to reparative justice for past harms, including various strategies of compensation, restitution (of land) and apologies or memorialization. In a similar vein, Tamar Cohen notes that in an Australian context, "For Aboriginal peoples affected by mining... rehabilitation represents a vision of the future-a future premised on greater control over their land" (Cohen, 2017, p. 137). In this sense, while technical remediation processes risk depoliticizing mining and its impacts through processes of environmental mitigation and improvement, an Indigenous ethics of remediation re-centres questions of justice and self-determination. 
Ultimately, if remediation is to contribute to environmental justice, it must be seen as a process of rebuilding or reconciling relationships and decolonizing land (Tuck and Yang, 2012). Following Tsosie, we argue that remediation processes can and should be used as a process for addressing colonial and environmental injustices and for decolonizing and healing land. In the context of settler colonial nations (including those with extensive mining histories like Canada, South Africa, the United States, and Australia), reconciliation with Indigenous peoples entails the confrontation of colonial histories (and their ongoing legacies) through processes of truth-telling, apology, and compensation or redress (Regan 2010; Truth and Reconciliation Commission of Canada, 2017). Indigenous scholarship critical of reconciliation emphasizes the decolonization of land in the redress of colonial relations (Tuck and Yang 2012; Coulthard 2014; Todd 2014; Simpson, 2017; McGregor, 2018). Thus, remediation discussions must include a restoration of Indigenous sovereignty in order for justice to be fully realized. While there are complex social, historical, and legal contexts to reconciliation and decolonization in different countries, remediation processes can begin to contribute to environmental justice through official apologies, recognition of injustices suffered due to mining, and compensation for past and ongoing harms. Including reconciliation within the $\mathrm{EJ}$ and remediation dialogue can also entail practical strategies for direct socio-economic involvement in management, monitoring and long-term care of remediated sites (Carroll, 2015).

\section{Remediation as Repair, Maintenance and Matters of Care}

Pulling together these wide-ranging concepts from ecological restoration, discard studies, environmental justice, and reconciliation we hope to emphasize the importance of an ethical approach to environmental remediation rooted in place and landscape. Such a process would confront both the social and material legacies of post-mining landscapes (and the systems and 
structures within which these legacies are produced). However, such a framework remains premised on the idea of achieving some 'end point' where remediation is complete, waste is contained, the community engaged, justice issues addressed, and some combination of economic, environmental, and cultural value has been returned or added to the mine site. Yet this presumption fails to recognize the ongoingness and indeterminacy of both the material effects of landscape degradation and the social relations constituted through environmental damage and remediation (Langhorst and Bolton, 2017). As noted above, many, if not most mine sites will remain incompletely restored or require long-term, even perpetual care and maintenance long after the active remediation phase. Maintaining a remediated site while ensuring Indigenous selfdetermination and environmental justice is not a straightforward process; further degradation of land and relationships is always a possibility. Acknowledging the challenges of ongoing care and maintenance requires attention to the social relations of repair and care.

The terms 'repair' and 'care and maintenance' are often used in the context of mine reclamation (Kempton et al., 2010; Kuyek, 2011); however their wider implications for remediation practices are rarely questioned. Though its etymology suggests notions of temporal return, acts of repair are akin to restoration - there may be an objective, an end goal, or an agreed upon (or contested) optimum state, but the thing being repaired or restored will never be exactly as it was. Repair is also related to the word reparation, echoing the issues of reconciliation and compensation noted above. Similar to debates around environmental restoration, recent literature on repair and maintenance highlights the social formations, politics, and power relations surrounding repair practices. This approach frames repair practices as intrinsically ethical activities that raise broad questions about "how we live with socio-technical systems," (Houston and Jackson, 2016, p. 1). Drawing attention to the social and ethical contexts of repair practices, Elizabeth Spelman argues that through repair, "from apologies and other informal attempts at 
patching things up, to law courts, conflict mediation, and truth and reconciliation commissions, we try to reweave what we revealingly call the social fabric" (Spelman, 2008, p. 127-128). Understanding repair and maintenance through this lens offers ongoing opportunities for creativity and adaptation throughout (and beyond) mine remediation processes.

Like remediation and restoration, repair and maintenance are not always inherently good (Barnes, 2016; Jackson, 2014). As Ureta (2014) points out (echoing critiques of restoration ecology), repair can also be seen as a normalization process that may be implicated in the maintenance of relations of power and order. As such, "maintenance and repair are moments of learning and of politics, as values and orders are being negotiated and re-made in and through restoration and reproduction" (Houston and Jackson, 2016, p. 3). In many cases, repair practices may reinforce the power of 'expert knowledge' (Henke, 2000; Barnes, 2016). A critical approach to repair practices in mining seeks to challenge this "normalization" by recognizing how environmental damage and pollution is normalized in extractive industries, while promoting repair as a site of ethical, creative, and accountable engagement.

To address the complex layers of histories, technologies, and politics at remediation sites requires going beyond repair, to a consideration of remediation as a 'matter of care' (Ureta, 2014; Puig de Bellacasa, 2017). In the context of remediation processes, terms such as caretaker or perpetual care invoke ideas of concern, responsibility, and even love for the environment and the social relations that sustain healthy ecosystems. In this sense, acts of repair and care can be mobilized to "serve as a gathering purpose: to hold together a thing" (Puig de la Bellacasa, 2011, p. 90). Care is a process of continually negotiating relations. Framing waste management as an act of care reflects everyday practices and the expectation of failure; "it proposes temporary and experimental ways to involve all the concerned parties in the search for alternative ways to live with our waste, in material, ethical and political terms" (emphasis added, Ureta, 2016, p. 1). 
In his study of a Chilean copper mine, Ureta (2016) outlines three important aspects of caring for and living with waste: care as tinkering, care as a form of 'affective entanglement' and care as a particular kind of power. Always experimental and tentative, care as tinkering shines light on the importance of the day-to-day maintenance of the infrastructure and relations through which waste is produced, managed, stored and maintained long-term (Mol et al., 2010). This not only applies to material fixes, but also to what Henke calls "social repair," (2000) or the tinkering with relationships that are shaped by waste. Care as an 'affective entanglement' acknowledges an "ethical command of taking into account all the entities involved in industrial solid waste, even the ones we dislike or are opposed to" (Ureta, 2016, p. 5; Puig de la Bellacasa, 2011, 2017; Hird, 2013). The management of waste must consider all participants, from disempowered communities, to more-than-human beings, to the material waste itself. Acts of care can also manifest as particular kinds of power, cherishing some things while excluding others (Martin et al., 2015; Ureta, 2016). Care may be framed as apolitical when governments or industries assert 'care for' communities and landscapes, but communities lose the political ability to care for themselves (Martin et al., 2015; Murphy, 2015).

Framing mine remediation and landscape repair as ongoing processes of care signifies a way to embrace both the uncertainty and responsibility of living with the legacies of mining, rather than perpetuating the illusion of our abilities to contain such waste forever. An ethics of repair and care can be usefully brought into conversation with the Indigenous ethics of remediation and justice noted above - as well as Indigenous conceptions of relation and reciprocity (LaDuke, 2005; Tsosie, 2015; Hoover, 2017; Simpson, 2017; McGregor, 2018). Both mining and remediation processes have restricted the abilities of Indigenous communities to care for their land, and for land to care for them. Following Bawaka Country et. al., framing remediation as a restoration of relations of care acknowledges that remediation processes must 
"not only Care for Country, but Care as Country" in an ongoing process of "co-becoming" with Land (2013, p. 195-196; see also Rose, 2007). An 'ethics of remediation' rooted in reciprocity and care for relations (animals, plants, humans, minerals, water, and waste) would re-establish Indigenous communities' ability to care as land within their own practices of healing (Watts, 2013).

\section{Conclusions: Rethinking Remediation}

When mines 'die' they do not simply disappear; they cannot be buried and forgotten about. Remediation or reclamation is an extension of the mining process; it alters the landscape, society, and economy, and can be both dangerous and beneficial for surrounding communities. A wide range of definitions and valuation processes are involved in remediation planning; there are many stakeholders with a variety of perspectives, realities, and practices. Remediation may engage multiple levels of government, consulting companies, mining and construction companies, Indigenous groups, local communities, heritage groups, and environmental organizations. Post-mining landscapes are shaped not only by the complex history of the mine, but also by the many different groups articulating their values, how these values are ranked hierarchically, and how waste transforms and moves over time and space. Yet with few exceptions, mine remediation planning processes remain largely industry and state-driven, governed by techno-scientific evaluations of risk and ecological conditions.

Pulling together such wide-ranging concepts as ecological restoration, discard studies, environmental justice, repair and maintenance and care, this paper provides theoretical openings for a more holistic, ethical approach to remediation planning. As this review has argued, rethinking remediation entails its redefinition to include not only technical environmental questions, but also the contested political, social, and cultural relations generated by extraction 
and its legacies. Doing so requires critical attention to the material flows, connections, and effects generated by mining, as well as their complex temporalities. Mineral extraction and its wastes produce environmental injustices (harms) that are implicated in (settler) colonial dispossession and other processes of social marginalization that must be addressed in equitable perpetual care and remediation processes. Alongside Langhorst and Bolton, we envision remediation as a "platform for debate in order to avoid erasure of contested and conflicted histories" (2017, p. 167) and a mechanism to confront the material challenges of perpetually contaminated landscapes. Incorporating practices of social repair and care into remediation activities draws critical attention to the ongoing process of healing damaged landscapes and relations, and can "help us locate immediate forms of technical work within wider moral and political orderings" (Houston, and Jackson, 2016, p. 9). In addressing environmental justice, we suggest remediation activities may create opportunities for marginalized communities to confront past injustices, to remedy negative legacies of mining, and to determine future relationships with post-mining landscapes.

New metaphors can help guide this reconceptualization. Writing about northern Sweden, Anna Storm (2014) invokes the metaphor of the scar to consider how communities relate to degraded environments. According to Storm, the recovery of post-industrial landscapes can be conceptualized as a 'scabbing' process, an intermediate stage where hierarchies are negotiated, values are defined, and perceptions of waste and future land uses are addressed. Scabbing, like repair and remediation, is a creative opportunity for how the space will be remembered, valued, and cared for in the future. Storm writes that, "To heal a mental or physical wound into a scar that one can live with is to recognize key signs of difficult or ambiguous pasts and to point towards possible reconciliation" (2014, p. 3). Possibilities for care, she suggests, can emerge from the wounds and the wreckage. 
Following Storm's scar and scabbing metaphors, this paper suggests that remediation can be seen as an opportunity for negotiating the contested history of a site, a call for justice, and a creative, ongoing discussion about environmental futures. Ethical remediation of landscapes extends far beyond technical questions of contaminant levels and ecological repair, or even monetary compensation for past harms: "the discussion about reparations... is a discussion of how the past, present, and future are co-joined and interdependent" (Tsosie 2015, p. 253). In the context of the remediation of mine waste, which is likely to persist into the distant future, this ethic extends to encompass duties towards future generations of humans and more-than-humans likely to occupy post-mining landscapes. Our re-evaluation of the term remediation points to an alternative conceptualization of remediation activity as an intervention in conflict and a promotion of reconciliation and relationality in search of better practices for living with and caring for damaged places and relationships.

\section{Acknowledgements}

Research for this paper was supported by Social Sciences and Humanities Research Council of Canada award number 435-2014-0968. The authors would like to thank John Sandlos, Anna Storm, and two anonymous referees for their valuable feedback on earlier drafts. 


\section{References}

Ali, S. H. 2003. Mining, the Environment, and Indigenous Development Conflicts. Tucson: University of Arizona Press.

Baeten, J., Langston, N. and Lafreniere, D. 2016. "A geospatial approach to uncovering the hidden waste footprint of Lake Superior's Mesabi Iron Range.” The Extractive Industries and Society 3: 10311045.

Baeten, J. 2017. "Contested landscapes of displacement: Oliver Iron and Minnesota's Hibbing District." Change Over Time 7 (1): 52-73.

Bainton, N.A. and S. Holcombe. 2018. The social aspects of mine closure: a global literature review. Centre for Social Responsibility in Mining (CSRM), Sustainable Minerals Institute (SMI), Brisbane: The University of Queensland.

Ballard, C., and Banks, G. 2003. "Resource wars: the anthropology of mining." Annual Reviews of Anthropology 32: 287-313.

Banfield, L and Jardine, C.G. 2013. "Consultation and remediation in the north: meeting international commitments to safeguard health and well-being." International Journal of Circumpolar Health 72 (1): $1-7$.

Barnes, J. 2016. "States of maintenance: power, politics and Egypt's irrigation infrastructure." Environment and Planning D Society and Space 35 (1): 1-19.

Bavington, D. 2011. Managed annihilation: an unnatural history of the newfoundland cod collapse. Vancouver, BC: UBC Press.

Bawaka Country, Wright, S., Suchet-Pearson, S., Lloyd K., Burrarwanga, L., Ganambarr, R., Ganambarr-Stubbs, M., Ganambarr, B., Maymuru, D., Sweeney, J. 2016. "Co-becoming Bawaka: towards a relational understandings of place/space.” Progress in Human Geography 40(4): 455475.

Bebbington, A., L. Hinojosa, D.H. Bebbington, M. L, Burneo, and X. Warnaars. 2008. "Contention and ambiguity: mining and the possibilities of development." Development and Change 39 (6): 887914.

Benford, G. 1999. Deep time: how humanity communicates across millennia (New York: Avon).

Berger, A. 2002. Reclaiming the American west. New York, NY: Princeton Architectural Press.

Bergmans, A., Sundqvist, G., Kos, D., and Simmons, P. 2015. "The participatory turn in radioactive waste management: deliberation and the social-technical divide." Journal of Risk Research 18 (3): 347-63. 
Bird, G. 2016. "The influence of the scale of mining activity and mine site remediation on the contamination legacy of historical metal mining activity." Environmental Science and Pollution Research 23 (23): 23456-23466.

Bradshaw, A. 1997. "Restoration of mined lands — using natural processes." Ecological Engineering 8: 255-69.

Brooks, D. 2015. Restoring the shining waters: superfund success at Milltown, Montana. Norman, OK: University of Oklahoma Press.

Browne, A. L., Stehlik, D., Buckley, A. 2011. "Social licences to operate: for better not for worse; for richer not for poorer? The impacts of unplanned mining closure for "fence line" residential communities." Local Environment: The International Journal of Justice and Sustainability 16 (7): 707-725.

Bullard, R. D., 1996. Environmental justice: it's more than waste facility siting. Social Science Quarterly, 77 (3), 493-494.

Carroll, C. 2015. Roots of our renewal: ethnobotany and Cherokee environmental governance. Minneapolis, MN: University of Minnesota Press.

Cohen, T. 2017. 'Bringing country back? Indigenous aspirations and ecological values in australian mine-site rehabilitation.' In ExtrACTION: impacts, engagements and alternative futures, edited by Jalbert, K. Willow, A., Casagrande, D., Paladino, S. New York, NY: Routledge.

Cooke, J., and M S Johnson. 2002. "Ecological restoration of land with particular reference to the mining of metals and industrial minerals: a review of theory and practice." Environmental Reviews 10 (1): 41-71.

Coulthard, G. 2014. Red Skin White Masks: Rejecting the Colonial Politics of Recognition. Minneapolis, MN: University of Minnesota Press.

Cram, S. 2015. "Becoming Jane: the making and unmaking of Hanford's nuclear body." Environment and Planning D: Society and Space 33 (5): 796-812.

Dance, A. 2015. "Northern reclamation in Canada: contemporary policy and practice for new and legacy mines." The Northern Review 41: 41-80.

Dillon, L. 2014. "Race, waste, and space: brownfield redevelopment and environmental justice at the Hunters Point Shipyard.” Antipode 46 (5): 1205-21.

Elliot, R. 1997. Faking nature: the ethics of environmental restoration. London, UK: Routledge.

Erikson, K. 1994. A new species of trouble: explorations in disaster, trauma, and community. New York, NY: W.W. Norton and Company. 
Francaviglia, R.V. 1991. Hard places: reading the landscape of America's historic mining districts. Iowa City, IA: University of Iowa Press.

France, R.L., ed. 2008. Healing natures repairing relationships: new perspectives on restoring ecological spaces and consciousness. Vermont: Green Frigate Books.

Gabrys, J. 2009. 'Sink: the dirt of systems.” Environment and Planning D: Society and Space 27 (4): 666-681.

Gedicks, Al. 2001. Resource rebels: native challenges to mining and oil companies. Cambridge, MA: South End Press.

Goin, P., \& Raymond, C. E. 2004. Changing mines in America. Santa Fe, NM: Center for American Places.

Graham, S. and Thrift, N. 2007. "Out of order: understanding repair and maintenance." Theory, Culture and Society 24 (3): 1-25.

Gray-Cosgrave, C., Liboiron, M., and Lepawsky, J. 2015. "The challenges of temporality to depollution and remediation." S.A.P.I.EN.S 8 (1): 1-10.

Gregson, N. and Crang, M. 2010. "Materiality and waste: inorganic vitality in a networked world." Environment and Planning A 42 (5): 1026-1032.

Hall, M. 2005. Earth repair: a transatlantic history of environmental restoration. Charlottesville: University of Virginia Press.

Hall, R. 2012. "Diamond Mining in Canada's Northwest Territories: A Colonial Continuity." Antipode 45 (2).: 376-93.

Halvaksz, J. A. 2008. "Whose closure ? Appearance, temporality and mineral extraction in Papua New Guinea." The Journal of the Royal Anthropological Institute 14 (1): 21-37.

Henke, C. J. 2000. "The mechanics of workplace order: toward a sociology of repair." Berkeley Journal of Sociology 44: 55-81.

Higgs, E., 2003. Nature by design. Cambridge, MA: MIT Press.

Hilson, G. 2000. "Sustainable development policies in Canada's mining sector: an overview of government and industry efforts." Environmental Science \& Policy 3 (4): 201-11.

Hilson, G. and Murck, B. 2000. "Sustainable development in the mining industry: clarifying the corporate perspective.” Resources Policy 26 (4): 227-38.

Hird, M. 2013. "Waste, landfills and an environmental ethic of vulnerability." Ethics and the Environment 18 (1): 1085-6633. 
Hobbs, R. and Norton, D. 1996. "Towards a conceptual framework for restoration ecology.” Restoration Ecology 4 (2): 93-110.

Hobbs, R. 2013. "Grieving for the past and hoping for the future: balancing polarizing perspectives in conservation and restoration." Restoration Ecology 21 (2): 145-48.

Hockley, D.E., and Hockley, L.C. 2015. "Some histories of mine closure, the idea." In Mine Closure Conference, edited by A.B. Fourie, M. Tibbett, L. Sawatsky, D. van Zyl. June 1-3 2015, Vancouver, Canada.

Holifield, R. 2012. "Environmental justice as recognition and participation in risk assessment: negotiating and translating health risk at a Superfund site in Indian country." Annals of the Association of American Geographers 102 (3): 591-613.

Hoover, E. 2017. The river is in us: fighting toxics in a Mohawk community. Minneapolis, MN: University of Minnesota Press.

Horowitz, L.S., A. Keeling, F. Lévesque, T. Rodon, S. Schott, and S. Thériault. 2018. "Indigenous peoples' relationships to large-scale mining in post/colonial contexts: toward multidisciplinary comparative perspectives." Extractive Industries and Society 5 (3). Elsevier: 404-14.

Hourdequin, M. and Havlick, D. G. 2015. "Introduction: ecological restoration and layered landscapes." In Restoring layered landscapes: history, ecology, and culture, edited by Marion Hourdequin and David. G. Havlick. Oxford, UK: Oxford University Press

Houston, L. and Jackson, S.J. 2016. "Caring for the "next billion mobile handsets: opening propriety closures through the work of repair." The International Conference on Information and Communication Technologies and Development, June 3-6, 2016, Anne Arbour, MI.

Howe, C., Lockrem, J., Appel, H., Hackett, E., Boyer, D., Hall, R., Schneider-Mayerson, M. et al., 2016. "Paradoxical infrastructures: ruins, retrofit, and risk." Science, Technology \& Human Values 41 (3): 547-565.

Hudson-Edwards, K., Jamieson, H.E., and Lottermoser, B.G. 2011. "Mine wastes: past, present, future." Elements 7 (6): 375-380.

Ialenti, V. 2014. “Adjudicating deep time: revisiting the United States' high-level nuclear waste repository project at Yucca Mountain.” Science and Technology Studies 27 (2): 27-48.

Jackson, S. 2014. "Rethinking repair." In Media technologies: essays on communication, materiality, and society, edited by T. Gillespie, P.J. Boczkowski, and K. Foot. Cambridge, Mass: The MIT Press.

Jakle, J. and Wilson, D. 1992. Derelict landscapes: the wasting of America's built environment. Lanham, MD: Rowman and Littlefield Publishers. 
Joly, T. 2017. Making productive land: utility, encounter, and oil sands reclamation in northeastern Alberta, Canada. Aberdeen: University of Aberdeen.

Katz, E. 1997. Nature as subject: human obligation and natural community. Oxford: Rowman and Littlefield Publishers, Inc.

Keeling, A. 2012. "Mineral waste." In SAGE Encyclopedia of Consumption and Waste: the Social Science of Garbage, edited by C. A. Zimring and W. L. Rathje. California: SAGE Publications.

Keeling, A. and Sandlos, J. 2009. "Environmental justice goes underground? Historical notes from Canada's northern mining frontier." Environmental Justice 2 (3): 117-125.

Keeling, A. and Sandlos, J., eds. 2015. Mining and communities in Northern Canada: history, politics and memory. Calgary, Alberta: University of Calgary Press.

Keeling, A. and Sandlos, J. 2017. "Ghost towns and zombie mines: the historical dimensions of mine abandonment, reclamation and redevelopment in the Canadian North.” In Ice blink: navigating northern environmental history, edited by S. Bocking and B. Martin. Calgary, AB: University of Calgary Press.

Kempton, H., Bloomfield, T.A., Hanson, J.L., and Limerick, P. 2010. "Policy guidance for identifying and effectively managing perpetual environmental impacts from new hardrock mines." Environmental Science and Policy 13 (6): 558-66.

Kenney, D., Stohs, M., Chavez, J., Fitzgerald, A., and Erickson, T. 2004. Evaluating the use of good neighbor agreements for environmental and community protection. Boulder, Colorado: Natural Resources Law Center, University of Colorado School of Law.

Kivinen, S. 2017. "Sustainable post-mining land use: are closed metal mines abandoned or re-used space?" Sustainability 9 (10): 1705.

Krupar, S.R. 2011. "Alien still life: distilling the toxic logics of the Rocky Flats National Wildlife Refuge." Environment and Planning D: Society and Space 29 (2): 268-90.

Krupar, S.R. 2013. Hot spotters report: military fables of toxic waste. Minneapolis, Minn: University of Minnesota Press.

Kuletz, V. L. 1998. The tainted desert: environmental ruin in the American West. New York: Routledge.

Kuyek, J. 2011. The theory and practice of perpetual care of contaminated sites. Yellowknive, Canada: Alternatives North submission to the Mackenzie Valley Environmental Impact Review Board.

LaDuke, W. 2005. Recovering the sacred: the power of naming and claiming. Cambridge, MA: South End Press.

Langhorst, J. and Bolton, K. 2017. "Reframing the Postindustrial: Landscapes of Extraction between Reclamation and Reinvention." Change Over Time, 7 (1): 158-182. 
Laurence, D. 2006. "Optimisation of the mine closure process." Journal of Cleaner Production 14: 285298.

Leech, B. 2011. "Boom, bust and the Berkeley Pit: how insiders and outsiders viewed the mining landscape of Butte, Montana." The Journal of the Society for Industrial Archeology 37 (1/2): 53 170.

Leech, B. 2018. The city that ate itself: Butte, Montana and its expanding Berkely Pit. Reno, NV: University of Nevada Press.

Leddy, L.C. 2013. Poisoning the serpent: the effects of the uranium industry on the Serpent River First Nation, 1953-1988. In The nature of empire and the empire of natures: Indigenous peoples and the Great Lakes environment, edited by Hele, K.S. Waterloo, ON: Wilfrid Laurier University Press.

Leopold, A. 1949. A sand county almanac. New York, NY: Oxford University Press.

Lepawsky, J., Liboiron, M., Keeling, A., and Mather, C. 2017. “Repair-scapes.” Continent, 6 (1).

Lerner, S. 2010. Sacrifice zones: the front line of toxic chemicals in the United States. Cambridge, Mass: MIT Press.

Li, T. M. 2007. The will to improve: governmentality, development, and the practice of politics. Durham: Duke University Press.

Liboiron, M. 2014. "Why discard studies?” Discard Studies blog. Available from https://discardstudies.com/2014/05/07/why-discard-studies/ [Accessed 15 November 2018].

Liboiron, M., Tironi, M., and Calvillo, N. 2018. "Toxic Politics: Acting in a permanently polluted world." Social Studies of Science 48 (3): 331-49.

Light, A. 2000. "Ecological restoration and the culture of nature: a pragmatic perspective.” In Restoring Nature, Perspectives from the Social Sciences and Humanities, edited by P.H. Gobster and R.B. Hull. Washington, DC: Island Press.

Lima, A.T., Mitchell, K., O’Connell, D.W., Verhoeven, J., and Van Cappellen, P. 2016. "The legacy of surface mining: remediation, restoration, reclamation and rehabilitation." Environmental Science and Policy 66: 227-233.

Lottermoser, B.G. 2010. Mine wastes: characterization, treatment and environmental impacts, third edition. Berlin: Springer.

Mah, A. 2012. Industrial ruination, community and place: landscapes and legacies of urban decline. Toronto, ON: University of Toronto Press. 
Martin, A., Myers, N. and Viseu, A. 2015. “The politics of care in technoscience." Social Studies of Science 45 (5): 625-641.

Martinez-Alier, J. 2001. "Mining conflicts, environmental justice and valuation.” Journal of Hazardous Materials 8: 153-170.

McDonald, P., Mayes, R., \& Pini, B. 2012. "Mining work, family and community: a spatially-oriented approach to the impact of the Ravensthorpe Nickel Mine closure in remote Australia." Journal of Industrial Relations 54 (1): 22-40.

McGregor, D. 2018. "Mino-mnaamodzawin: achieving indigenous environmental justice in Canada." Environment and Society 9(1): 7-24.

Merriam-Webster Dictionary. 2016. "Definition of remedy." Available from: http://www.merriamwebster.com/dictionary/remedying [Accessed November 2016].

Mohai, P., Pellow, D. and Roberts, J. T. 2009. "Environmental Justice." Annual Review of Environment and Resources, 34(1), pp. 405-430.

Mol, A., Moser I. and Pols, J. 2010. "Care in practice: on normativity, concepts and boundaries." Technoscienza Italian Journal of Science and Technology Studies 2 (1): 73-86.

Murphy, M. 2015. "Unsettling care: troubling transnational itineraries of care in feminist health practices." Social Studies of Science 45 (5): 717-37.

Nixon, R. 2011. Slow violence and the environmentalism of the poor. Cambridge, MA: Harvard University Press.

O’Reilly, K. 2015. "Liability, legacy and perpetual care: government ownership and management of the Giant Mine, 1999-2015." In Mining and communities in Northern Canada: history, politics and memory, edited by A. Keeling and J. Sandlos. Calgary, AB: University of Calgary Press.

Ottinger, G. 2013. Refining expertise: how responsible engineers subvert environmental justice challenges. New York, NY: NYU Press.

Peachmann, G. 2009. 101 things to do with a hole in the ground. Cornwall, U.K.: Post-Mining Alliance.

Pepper, M, C P Roche, and G M Mudd. 2014. "Mining Legacies - Understanding Life-of-Mine Across Time and Space," Life-of-Mine Conference, Brisbane, Australia: 449-465.

Pini, B., Mayes, R., \& McDonald, P. 2010. "The emotional geography of a mine closure: a study of the Ravensthorpe nickel mine in Western Australia." Social \& Cultural Geography 11 (6): 559-574.

Puig de la Bellacasa, M. 2011. "Matters of care in technoscience: assembling neglected things." Social Studies of Science 41 (1): 85-106. 
Puig de la Bellacasa, M. 2017. Matters of care: speculative ethics in more than human worlds. Minneapolis, MN: University of Minnesota Press.

Quivik, F. 2001. "Integrating the preservation of cultural resources with remediation of hazardous materials: an assessment of Superfund's record." The Public Historian 23 (2): 47-61.

Regan, P. 2010. Unsettling the settler within: Indian residential schools, truth telling and reconciliation in Canada. Vancouver, BC: UBC Press.

Reno, J. 2015. “Waste and waste management.” Annual Review of Anthropology 44: 557-72.

Rixen, A., \& Blangy, S. 2016. "Life after Meadowbank: exploring gold mine closure scenarios with the residents of Qamini'tuaq (Baker Lake), Nunavut.” The Extractive Industries and Society 3 (2): 297-312.

Roberts, S., Veiga, M., and Peiter, C. 2000. Overview of mine-closure and reclamation in the Americas: executive summary. Vancouver, Canada: International Development Research Center.

Robertson, D. 2006. Hard as the rock itself: place and identity in the American mining town. Colorado: University of Colorado Press.

Roche, C., and Judd, E. 2016. Ground Truths: Taking responsibility for Australia's mining legacies. Mineral Policy Institute Report. Available from: http://www.mpi.org.au/2016/06/grond-truthtaking-responsibility-for-australias-mining-legacies/.

Rohwer Y., and Marris, E. 2016. "Renaming restoration: conceptualizing and justifying the activity as a restoration of lost moral value rather than a return to a previous state." Restoration Ecology 24 (5): 674-79.

Rose, D.B. 2007. "Recursive epistemologies and an ethics of attention." In Extraordinary anthropology: transformations in the field, edited by J.G. Goulet and B. Miller. Lincoln, NB: University of Nebraska Press.

Simpson, Leanne Betasamosake. As we have always done. Minneapolis, MN: University of Minnesota Press.

Smith, D. 1987. Mining America: the industry and the environment, 1800-1980. Lawrence, KA: University Press of Kansas.

Smith, L. 2014. "On the 'emotionality' of environmental restoration: narratives of guilt, restitution, redemption and hope." Ethics, Policy \& Environment 17 (3): 286-307.

Spelman, E.V. 2008. "Embracing and resisting the restorative impulse." In Healing natures repairing relationships: new perspectives on restoring ecological spaces and consciousness, edited by R. L. France. Sheffield, VT: Green Frigate Books. 
Steenhof, P.A. 2015. "Development of international standards for mine reclamation management." Mine Closure Conference. Vancouver, Canada, 1-3 June, 2015.

Storm, A. 2014. Post-industrial landscape scars. New York, NK: Palgrave Macmillan.

The Bureau of Land Management. 2007. Abandoned mine lands: a decade of progress reclaiming hardrock mines. The U.S. Forest Service, publication number: FS-891.

Todd, Z. 2014. "Fish pluralities: human-animal relations and sites of engagement in Paulatuuq, Arctic Canada." Études/Inuit/Studies 38 (1-2): 217.

Truth and Reconciliation Commission of Canada. 2017. "Reconciliation: towards a new relationship." Available from: http://www.trc.ca/websites/reconciliation/index.php?p=356 [Accessed 31 August, 2017].

Tsosie, R. 2015. "Indigenous peoples and the ethics of remediation: redressing the legacy of radioactive contamination for native peoples and native lands." Santa Clara Journal of International Law, 13 (1), 203-272.

Tuck, E. \& Yang, K. 2012. "Decolonization is not a metaphor.” Decolonization: Indigeneity, Education, \& Society 1(1): 1-40.

Ureta, Sebastián. 2016. "Chemical Rubble : Historicizing Toxic Waste on a Former Mining Town in Northern Chile.” Environment \& Society Portal, Arcadia Autumn 2016, no. 20. Rachel Carson Center for Environment and Society. Available from: http://www.environmentandsociety.org/node/7704 [Accessed 1 March 2017].

Ureta, S. 2014. "Normalizing transantiago: on the challenges (and limits) of repairing infrastructures." Social Studies of Science 44 (3): 368-92.

Ureta, S. 2016. "Caring for waste: handling tailings in a Chilean copper mine." Environment and Planning A 48 (8): 1532-48.

Voyles, T.B. 2015. Wastelanding: legacies of uranium mining in Navajo Country. Minneapolis, MN: University of Minnesota Press.

Walker, G. and Bulkeley, H. 2006. “Geographies of environmental justice.” Geoforum 37 (5): 655-659.

Watts, V. 2013. "Indigenous place-thought \& agency amongst humans and non-humans (First Woman and Sky Woman go on a European world tour!)" Decolonization: Indigeneity, Education \& Society, 2(1), pp. 20-34.

Whitehead, A.N. 1920. Concept of nature. Cambridge, MA: Cambridge University Press.

Whitmore, A. 2005. “The emperor's new clothes: sustainable mining?” In Sustainable mineral operations in the developing world, edited by B.R. Marker, M.G. Petterson, F. McEvoy, and M.H. Stephenson. London, UK: Geological Society Special Publications. 
Wiebe, S.M. 2017. Everyday exposure: Indigenous mobilization and environmental justice in Canada's Chemical Valley. Vancouver, BC: UBC Press.

Women's Earth Alliance and Native Youth Sexual Health Network. 2016. Violence on the land, violence on our bodies: building an Indigenous response to environmental violence. Available from: http://landbodydefense.org/uploads/files/VLVBReportToolkit2016.pdf [Accessed, 10 November, 2018].

Worrall, R. Neil, D. Brereton, D. and Mulligan, D. 2009. “Towards a sustainability criteria and indicators framework for legacy mine land.” Journal of Cleaner Production 17: 1426-43. 
